\title{
Transcription Factor SOX-17
}

National Cancer Institute

\section{Source}

National Cancer Institute. Transcription Factor SOX-17. NCI Thesaurus. Code C114835.

Transcription factor SOX-17 (414 aa, $44 \mathrm{kDa}$ ) is encoded by the human SOX17 gene.

This protein plays a role in organogenesis. 